This is a self-archived - parallel published version of this article in the publication archive of the University of Vaasa. It might differ from the original.

\title{
Digital Entrepreneurial Internationalizers: Definitions, Theoretical Implications, and Research Avenues
}

Author(s): Gabrielsson, Mika; Fraccastoro, Sara; Ojala, Arto; Rollins, Minna

Title: Digital Entrepreneurial Internationalizers: Definitions, Theoretical Implications, and Research Avenues

Year: $\quad 2021$

Version: Published version

Copyright (C)2021 Hawaii International Conference on System Sciences. This article is an open access article distributed under the terms and conditions of the Creative Commons Attribution-NonCommercialNoDerivatives 4.0 International (CC BY-NC-ND 4.0) license, https://creativecommons.org/licenses/by-nc-nd/4.o/

Please cite the original version:

Gabrielsson, M., Fraccastoro, S., Ojala, A. \& Rollins, M. (2021). Digital Entrepreneurial Internationalizers: Definitions, Theoretical Implications, and Research Avenues. In Proceedings of the 54th Hawaii International Conference on System Sciences (HICSS 2021), 5069-5078. University of Hawaii. http://hdl.handle.net/10125/71235 


\section{Digital Entrepreneurial Internationalizers: Definitions, Theoretical Implications, and Research Avenues}

\author{
Mika Gabrielsson \\ University of Eastern \\ Finland \\ mika.gabrielsson@uef.fi
}

\author{
Sara Fraccastoro \\ University of Eastern \\ Finland \\ sara.fraccastoro@uef.fi
}

\author{
Arto Ojala \\ University of Vaasa \\ arto.ojala@uwasa.fi
}

\author{
Minna Rollins \\ University of West \\ Georgia \\ mrollins@westga.edu
}

\begin{abstract}
Recent research has advanced our understanding of digital entrepreneurship and how digitalization impacts on internationalization. However, we still lack a clear understanding of what constitutes a digital entrepreneurial internationalizer (DEI). This paper aims at filling this gap by bridging research on digital entrepreneurship and that on digital internationalization, and by augmenting their applicability to managerial phenomena. We do this by offering an improved definition and criteria to understand what constitutes a digital firm. Then, based on literature on digitalization, digital entrepreneurship, and international entrepreneurship, we conceptualize DEI according to the criteria of digital and internationalization earliness. That conceptualization means we can present a matrix, in which a new typology of the firm-the Born Global \& Digital-emerges. We introduce examples of everyday successful business ventures that illustrate this and other types of DEIs. We then outline theoretical implications and future research avenues that could extend the conceptualization.
\end{abstract}

\section{Introduction}

Digitalization of products and services encourages greater flexibility by separating function from form and content from medium [60]. Although digitalization of firms is not a new phenomenon, the definitions of digital firms and the nature of digital entrepreneurship overall are not clear in the existing research in entrepreneurship [39; 57]. While the current research provides some conceptualizations of digital entrepreneurship [e.g. 39] or internationalization of born digitals [38], we argue that there is a need for further conceptualization of what constitutes a DEI.

The current international business literature focusing on the internationalization process of firms has gradually started to take account of the changes brought by digitalization to many of a firm's functions, which relate to the firm's international operations. Starting from the early 2000s, researchers have increasingly raised questions regarding the impact of the Internet and digital technologies on the ways that firms operate and create value in international markets. Besides having practical implications, digitalization brings changes to theories and conceptual frameworks analyzing international business phenomena. This becomes particularly relevant when scrutinizing firms that not only rely on digital platforms and infrastructure for their communication, marketing, sales, and delivering activities [39], but especially for those having purely digital value offerings. As Nambisan [39, p. 1030] points out "limited effort has been made on theorizing the role of specific aspects of digital technologies in shaping entrepreneurial opportunities, decisions, actions, and outcomes." To fill the gap in the existing literature, this paper focuses on how digital entrepreneurial internationalization differs from the traditional internationalization of firms. We define DEIs and categorize them into four typologies, based on two dimensions: digital earliness and internationalization earliness. Our typologies illustrate that Born Global \& Digital firms differ markedly from other digital ventures.

By conceptualizing and defining DEIs, we contribute to the current research on digital entrepreneurship and internationalization of firms. We discuss the theoretical implications that this new typology of firms brings to international business and entrepreneurship literature, by emphasizing the role 
that Born Global \& Digital firms play in today's business. The type stands out as a new typology of the firm, where digitalization and internationalization are attained soon after the firm's inception.

In the next section, we describe the theoretical foundation. After that, we present our conceptualization of DEIs and introduce a matrix outlining the four typologies of this venture. We conclude this paper with the theoretical contributions and the avenues for future research.

\section{Theoretical Foundation}

\subsection{Digitalization of the firms}

Digitalization refers to transformation of business processes so that the majority of the information is handled in a digital format [59]. This transformation is enabled by digitization that converts an analog information into a digital format (binary code) as series of $0 \mathrm{~s}$ and $1 \mathrm{~s}$. The conversion makes it possible to transfer physical products (artifacts) like books into digital form (digital artifacts). When an artifact is in a digital form, digitalization supports activities that help make more radical changes as digital artifacts have high malleability compared to physical artifacts [39; 59]. For instance, when a printed book is published, a publishing house cannot change the content of the book without printing a new edition of the book. However, when the book is available in a digital form, a printing house can change and modify the content whenever needed and these changes are available to readers immediately. So, the digital artifact can evolve even after it has been launched to the market or taken into use by customers.

Software based products, services, and platforms also represent digital artifacts. In the case of software, software firms can make changes to their software after launching it. Those changes might include localization and customization to new market segments and countries, or new product updates to reduce technical debt. That is, digital artifacts are, depending on their openness: editable, interactive, and reprogrammable [29,30]. Further, they are product and country agnostic meaning that digitalization enables the use of digital artifacts through different equipment and regardless of geographical location [23; 30; 60] (of course, the usage and its extent depend on several issues like IPrights, local regulations, etc.).

Digital platforms can be defined as extensible codebases where third parties can add complementarities in the form of new modules and services $[15 ; 55]$. A common aspect of all digital platforms is that they form two or multisided markets around the platform $[16 ; 18]$. The success of any platform is dependent on how platform owners can create a critical mass of users [42] for the platform. In two or multisided markets this means attracting enough users and content providers to form the market around the platform. Creation of multisided markets is dependent on different mechanisms like quality, quantity, diversity of the content, etc. [1]

Digital platforms cover platforms that provide digital content (such as Spotify and Netflix), software (such as Android or iOS), sharing economy services (such as Uber and AirBnB), a combination of digital and physical services and products (such as Amazon) [see e.g. $14 ; 31 ; 45$ ]. There are many different types of digital services provided through platforms. Some of the services are purely digital whereas some of the services combine both digital and physical components. It is also important to note that firms such as Amazon and Google provide a wide variety of both physical and digital goods. For instance, Google sells Google Nest that is a physical product whereas Google Books and Android are purely digital services. This makes the disjunction between digital and non-digital firms a far more complex phenomenon than proposed, for example, by Monaghan et al. [38] who apply the definition by UNCTAD [56]. Recently, Monaghan et al. [38] brought together the born digital firms and internalization model by Johanson and Vahlne [27]. The new model proposed describes the born digital firms as firms that fulfill three criteria [38]: First, digital firms build and leverage digital infrastructure. Second, digital firms rely on digital infrastructure to accrue communication, collaboration and/or computing capabilities, capabilities that allow the firm to both create and sell its offering online through a digital business model. Third, born digital firms are digital from inception [38]. In addition, Monaghan et al. [38] suggest that for born digital firms early and rapid internationalization is often intentional.

Based on Monaghan et al.'s [38] definition, telecom and software firms are categorized as nondigital firms as they do not rely on the Internet to fulfill production and delivery activities. However, several software firms like Adobe (categorized as a non-digital firm by Monaghan et al. [38]) have cloud services (like Adobe Creative Cloud) where software tools and content are available through the Internet. Further, firms like Samsung and Vodafone (also categorized as non-digital by Monaghan et al. [38]) provide several digital cloud services over the Internet. Hence, we cannot categorize firms as either digital or non-digital-based on their trade name but propose that we need to consider the entire value 
chain of the firm when defining the digital firm. As Vadana and colleagues [57] point out, the digitalization affects the value chain and the functions in the organization such as marketing, sales, and customer support.

In this paper, we define a digital firm as having the following characteristics:

(1) the products or services are available in a digital format comprising binary codes as series of " $0 \mathrm{~s}$ " or " $1 \mathrm{~s}$ " and are thus based on digital artifacts,

(2) the firm's products or services can be marketed and sold by relying on digital infrastructures (the Internet, email, etc.), and

(3) the firm's products or services can be delivered by relying on digital infrastructures (the Internet, email, etc.).

\subsection{Digital entrepreneurship}

The entrepreneurship literature reveals that entrepreneurship consists of the nexus of two phenomena: the emergence of an opportunity and the agency of an entrepreneurial individual [50]. Digitalization can be expected to fundamentally change both phenomena by making the processes and outcomes behind entrepreneurial opportunities less bounded and the locus of entrepreneurial agency less predefined [39]. Consider for instance how much flexibility the digital artifacts bring to the product and services introduction rate and adaptability to various domestic and foreign markets and segments. The features of a digital game can be altered after its introduction and it can be adapted to suit the language and other cultural requirements of foreign markets. Furthermore, the entrepreneurial agency is often open and distributed between several players, increasingly involving producers of digital platforms and application providers, but also end-users, as in multiplayer games. From the opportunityentrepreneur nexus point of view, digital technologies may also have a significant role in connecting the two, an aspect which we will cover next.

The opportunity formation process typically consists of identification, evaluation, and exploitation [49] and it is important to consider how digital technologies facilitate this process alongside the opportunity itself and the individual entrepreneur. During the identification phase, digital technology may play an important part in either discovery or creation of the opportunity [2]. The recent advancements that have happened in assisting a search through for instance Google have enhanced tremendously the discovery of opportunities. The role of entrepreneurial creativity has probably also been stimulated by the advances in technology; examples would include Airbnb and Uber that were created through digital platforms by entrepreneurial individuals who recognized the new opportunities facilitated by technological advances. Opportunity evaluation is also increasingly assisted by artificial intelligence and digital management information systems. Finally, digitalization is essential when opportunity exploitation is considered, for instance through linking the entrepreneur to resource- and module-networks [54], which may lead to the restructuring of the entire value chain. Consider for instance, the importance of mobile game developers being able to access the necessary financial resources and coding talent, and of having routes to distribute digital games as modules through the Apple or Google digital marketplaces. In order to understand the role of digitalization in opportunity formation, we need to examine how it changes the nature of the opportunity itself and how the role of the entrepreneur is changing, and also how it facilitates the interaction between the two phenomena during the identification, evaluation, and exploitation of the digital opportunity.

When referring to digital entrepreneurship, we use the definition by Kelestyn and Henfridsson [32, p. 2] who define it as the "users' practice of seizing digitally enabled innovation opportunities discovered in their everyday life to build new business ventures." Owing to the nature of digital technology reach, most digital entrepreneurial ventures also have an international, if not a global, market reach. Therefore, they are international entrepreneurs or at least that is a natural expansion path for them.

\subsection{International entrepreneurship}

International entrepreneurship has been defined as consisting of "a combination of innovative, proactive, and risk-seeking behavior that crosses national borders and is intended to create value in organizations" [37, p. 903]. The updated definition of international entrepreneurship from Oviatt and McDougall [44] states that "international entrepreneurship is the discovery, enactment, evaluation, and exploitation of opportunities - across national borders - to create future goods and services" [44, p. 540].

Based on the review of previous literature, it is evident that research has advanced our understanding of what constitutes digital entrepreneurship [39] and digital internationalization [38]. By merging these two research areas and bearing in mind the characteristics of international entrepreneurship [44], we define DEIs and offer examples from business practice. 


\section{Timing and Earliness of Digitalization and Internationalization}

The entrepreneurial activities of the founder always occur in relation to time [28]. We can indicate a chronological time point when the entrepreneur recognizes an opportunity and when a firm is established or when the first internationalization activity takes place. Distances between these time points measure duration.

The literature has conceptualized timing related to internationalization as consisting of three constructs: (1) earliness, which can be defined by the duration between the recognition of the opportunity, or simply firm establishment, and the first sales to international markets; (2) country scope to a specific level, which relates to the number of countries in which the firm operates relative to the duration of expansion; and (3) international commitment, in terms of the percentage of the increase in foreign revenue from inception [44].

The timing of digitalization from the innovation development perspective concerns whether digitalization is implemented from inception or during a transformation later in the technology lifecycle. This depends on many factors, such as the nature of the industry, which can be either relatively dynamic or stable [17]. For instance, in a dynamic market, such as that of iOS and Android applications, the digitalization probably calls for an experimentation-based process, whereas in a more stable industry, such as that producing cars or elevators, an analogical process that builds on the cumulative development in the industry may suffice [25].

Following the same logic of the timing of internationalization, we can also conceptualize the timing of digitalization. Accordingly, we can define (1) earliness as the duration between the recognition of the opportunity, or simply firm establishment, and the first introduction to markets of digital goods and services; (2) value chain scope to a specific level, which relates to the number of value chain functions in which the firm applies digitalization relative to the duration of existence; and (3) digitalization commitment, in terms of the percentage of digital revenue increase from inception.

From, the perspective of progressing with defining DEIs, we consider the earliness to be the most important aspect of time of digitalization. However, we believe the scope and commitment to be important research parameters for empirical investigation of firm development over time.

\subsection{Defining digital entrepreneurial Internationalizers}

When looking at the entrepreneurial firms operating in international markets and having digital value offerings (according to our definition of digital firm- see above- Section 2.1), it is interesting to notice that despite these firms being similar in some ways, their approach to both digitalization and internationalization varies and spurs differences that reflect respectively on their digitalization and internationalization behaviors. Current literature has provided examples of digital entrepreneurship [39] and digital internationalization [38], however it has not yet provided a compelling definition of DEIs. We consider a firm to be a DEI when its products or services are based on digital artifacts and whose identification, evaluation, and exploitation of opportunities through value chain activities can be digitalized, and the firm is entrepreneurial in terms of innovativeness, proactiveness, and risk-seeking behavior, and it crosses national borders as part of its intention to create value in organizations.

Further, we build on the entrepreneurial characteristics and those of earliness, with regard to digitalization and internationalization, typically restricted to the three first years from foundation, when categorizing DEIs as either happening at inception or in later stages of the firm's existence. The time to be set for this demarcation line is however, very much related to the industry in question [20], and we therefore later refer to from inception or a very short time after the foundation of the firm. In some industries the time period from the firm's foundation to possible product commercialization may be close to zero, whereas in some industries as much as six years could be spent in the research and development phase before the question of digitalization or internationalization is relevant.

In DEIs, the approach to international markets can either happen from inception or after a very short domestic-phase; and therefore follow models typical of firms that international business literature refers to as Born Global or International New Ventures [e.g. 6; $33 ; 40 ; 43 ; 46]$ or by following incremental internationalization [e.g. 26; 27]. We use the threeyear threshold definition used by researchers in the international business realm to refer to Born Globals (ventures that derive more than $25 \%$ of their sales from global markets within three years of their establishment, [see $20 ; 33 ; 46 ; 47$ ]) and extend it to digital firms. Accordingly, we refer to a firm as born 
digital if it meets the criteria for digitalization (see definition in Section 2.1) within three years of inception (leaving it to empirical investigation whether the $25 \%$ demarcation line with regard to commitment of $25 \%$ of digital sales would also be useful).

Our categorization yields a matrix (see: Figure 1) in which four categories of DEI emerge. We label the categories as follows: (i) Born Global \& Digital, (ii) Born Global Gradually Digital, (iii) Born Digital Gradually Global, and (iv) Gradually Global \& Digital.

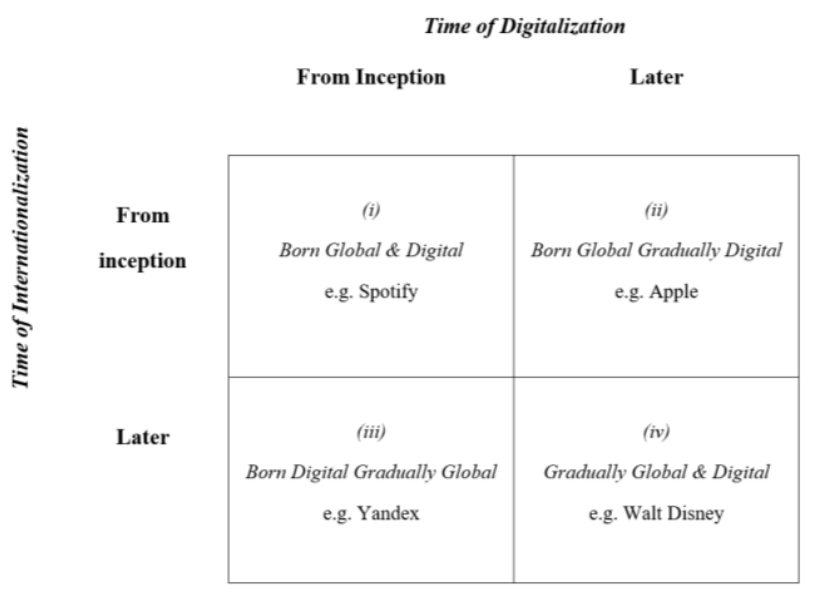

Fig. 1 Typologies of Digital Entrepreneurial Internationalizers

Firms that we label (i) Born Global \& Digital are ventures whose value offerings are available in digital format of binary codes (according to our definition of a digital firm, see above in Section 2.1), from the moment they are created and serve global markets soon after their inception. A famous example of such a firm is Spotify, an international audio streaming platform founded by two Swedish entrepreneurs in 2006, which became global soon after being launched. Recent literature has shown how digitalization facilitates early internationalization by enabling easier access to information about foreign markets and by reducing costs connected to geographical distance $[9 ; 35]$.

We refer to firms that have served global markets since their inception, but whose value offerings shifted to being digital only gradually as (ii) Born Global Gradually Digital. The category would encompass an entrepreneurial venture that met the requirements of digital firms only incrementally. A practical example of this category are those American and European highly entrepreneurial firms that immediately went global by providing tangible products. However, with time and given the incremental permeation of digital technologies throughout business, they gradually shifted their value offering to digital endeavors. An example of this category is Apple, the entrepreneurial venture that was founded in 1976 in California and closed its first authorized Japan dealership in 1977. The company started by offering computers worldwide and gradually shifted its product line to include digital offerings, such as iWebservices in 2000, iTunes in 2003, and iOS applications in 2007.

Similarly, we categorize those firms that incrementally approached foreign markets in line with the traditional international business theories [26; 27], but that fulfilled the requirements for a digital firm at inception as (iii) Born Digital Gradually Global. In this category, we find for instance purely digital entrepreneurial ventures that decided to focus on internal markets, because of their large size, such as Chinese or American firms, or those firms whose products and services are marketspecific or country-specific, and therefore the decision to enter each international market is one only taken over time. An exemplary instance of this category can be represented by Yandex, a now multinational corporation offering a wide-range of internet-related products and services established in 1997 by Russian entrepreneurs, who expanded to the first international market (Ukraine) only in 2005. Another example of this category is the Chinese firm Alibaba (founded in 1999) that specializes in ecommerce, retail, Internet-based technology. Alibaba has rapidly expanded into international markets over the past five years. In addition, PayPal, an American digital payment platform was founded 1998, but it did not start its international expansion until the mid 2000s.

Finally, we refer to those firms that have approached both digitalization and internationalization gradually as (iv) Gradually Global \& Digital. An example of this category are firms that for various reasons, such as those related to entrepreneurial decision-making, and knowledge about foreign markets have expanded into foreign markets only in the later stages of their development [26; 27]. In tandem with this approach is that to digitalization, where value offerings shifted to digital endeavors with time and incrementally. An example of this category can be provided by those more established firms that gained a foothold in their home markets by delivering products and services that were 
only partially, if at all, digital. As digital technology developed, the firms adapted their systems, operations, and delivery strategy accordingly and moved into serving international markets. The Disney Corporation is an instance of a Gradually Global \& Digital firm. Created by an entrepreneur (Walt Disney) in the early 1920s, the firm started by making short films with animated characters solely for the consumption of the American market. The venture gradually expanded and became a corporation selling animated movies internationally. With the advent of technology, the company gradually shifted from offering movies in theaters, to VHS and DVD formats. In 2019, the firm launched a subscription video on-demand streaming service, based on a platform called Disney Plus, through which it globally distributes films and television series produced by the Disney Corporation.

\section{Theoretical Implications and Research Avenues}

In this paper, our aim was to create a definition of DEIs and to present the typology of firms that qualify as such. Our matrix was built on two dimensions, earliness of digitalization and of internationalization. In our matrix, we noticed that many recently created businesses were categorized as a Born Global \& Digital firm. We suggest that this category of firms also has the highest impact on changing international business practices and theories. In fact, the business development triggered by digital innovations and their characteristics have an effect on how the entrepreneurial ventures approach the opportunities [2; 39], especially when considering the international business endeavor $[38 ; 40 ; 57]$. Next, we describe how the effects of the rise of Born Global \& Digital firms may change some tenets of international business research.

Digitalization has the potential to transfer entire value chains to online domains [see 7; 57]. That would have profound implications for how goods and services are produced, marketed, and delivered as well as on how ideas, decisions, and activities among value chain partners are communicated, orchestrated, and implemented. From a scholarly perspective, this translates as a likelihood of disrupting the basic assumptions on which some of the theories of the firm are built. In this respect, we suggest that the characteristics of digital artifacts may have an effect on the validity and applicability of some traditional theories of the internationalization of the firm. In particular, we discuss what changes could affect international business tenets such as the network approach by Johanson and Vahlne [27], the CAGE (Culture, Administration, Geographic, and Economic distance) model [21], and internalization theory [10]. Nevertheless, these challenges also introduce avenues for future academic research that we outline and that we believe are worthy of pursuing further.

First, important theoretical changes could occur in the networking approach, which emphasizes the relevance of building a network of connections among international business partners and becoming embedded in that network [27]. Earlier research has shown that the digital characteristics of global online reach and widespread connectivity of social media platforms enable firms to offer digital value offerings, to promote themselves, to enter international networks, and facilitate the process of overcoming the liability of outsidership through trustbuilding mechanisms $[19 ; 51]$.

However, in the case of firms commercializing purely digital goods and services, the basic assumptions of networking such as trust-building or bilateral interdependence could be questioned [38]. In fact, the trustworthiness of digital services is verified through online payment certification, reputation ratings, and online certification through independent verifying authorities [5;11]. Furthermore, bilateral interdependence involving the investment of time and resources by the contracting parties is often reduced, if not even erased. This happens for instance when commercializing platforms and subscription services, which are immediately available to global markets and where the communication and the nature of transactions with end-users is instant and frequent [6; 12].

Second, the liabilities typical of internationalizing ventures, such as newness, smallness, and foreignness [34] may become less of a burden for DEIs [see 3]. In fact, the characteristics of digital artifacts such as editability and reprogrammability allow these firms to amend the content of their digital value offerings instantly and independently [41]. Software interfaces that allow language modifications to the existing platforms and websites, and their online availability, make it possible to offer digital products and services that are instantly available to geographically dispersed buyers who speak different languages and come from different cultural backgrounds. Being a newcomer in a new foreign market [Newness- 54] is not necessarily a liability any longer, and actually firms can leverage digital artifacts' characteristics to expand to many international markets quickly and thus to accrue earnings. Similarly, owing to online advertising and marketing campaigns led through the Internet such as those in the form of search engine optimization and 
the pop-up advertisements, firms can rather inexpensively target customers who present cultural, geographical, and personal differences without having to invest vast amounts of money in nonvirtual media [cf. 36]. We suggest that this may have a direct impact on the survival of the firm when they are immersed in the initial commercialization of products and services and lacking in financial resources [-Smallness-, 22], and when they are foreign entrants into a new market [-Foreignness-61, 62].

Third, the four pillars of cultural, administrative, geographical, and economic distance of the CAGE Model [21], a theoretical framework extensively used in international business research to explain how firms coordinate (cultural, administrative, geographic, and economic) distance when internationalizing [see also 8], could become less relevant in the context of Born Global \& Digital firms. Recently, Shaheer and Li [48] showed that the international penetration of platform businesses is still subject to CAGE distances that act as barriers to the users' adoption of the platforms. That particular research, however, focuses on platform businesses operating in business-to-consumer markets. We believe that researchers should question whether those dimensions still matter for firms offering not only digital platforms, but also a broader variety of digital products and services also in business-tobusiness markets. We argue it is interesting to analyze what is the role of digitalization on the dimensions of distance. In fact, earlier research has shown that there is interaction among digital artifacts' characteristics and cultural and geographical dimensions of distance on the internationalization of the firm [41]. Future research could look at the interaction of the relevance of CAGE distances and that of digital technologyrelated aspects and issues, such as when firms encounter technical bottlenecks during internationalization [40].

In terms of the four dimensions of distance of the CAGE model, future research could possibly explore the questions such as: Do cultural issues still play a central role in the internationalization of DEIs? This has so far been a central issue in the international business debate [8]. Does online trust (for instance enabled by online ratings and users' reviews of digital goods and services) diminish cultural and diversity distance encountered when commercializing digital products and services in international markets? How does this affect country-specific quality associations? From a practical point of view, this aspect needs to be considered by firms not only when producing their digital value offerings, but also when branding themselves and selling internationally. Does digitalization remove inequality between DEIs from different genders, races, ethnic groups, and age? Learning how to leverage the characteristics of digital artifacts can help such firms to overcome cultural distances [41] and diversity biases.

Moreover, future research could cross-pollinate administrative and political issues in international business by looking at how the commercialization of digital goods and services affects administrative distance. For instance, would the exchange of digital products through digital infrastructure and by means of online payments that do not entail the intervention of banks or single administrators (e.g. Euros, US Dollars, etc.), but bitcoins or other cryptocurrencies affect administrative distance? In these terms, would there be an effect on the exchanges among firms and consumers using different monetary systems? Would there be effects on the sales of digital products of firms coming from countries with weaker legal and financial institutions?

We believe that geographic distance, referring to the lack of common borders and physical remoteness [21], has the highest potential to be reduced owing to digital infrastructure and the characteristics of digital artifacts that make digital goods and services immediately available to global marketplaces $[38 ; 39$; 40]. Future research could thus look at the role played by geographic distance, if any, in the case of DEIs?

In addition, it would be interesting to examine how digitalization interacts with the level of economic development of the country where the product or service is being commercialized or purchased. Moreover, we might ask what are the consequences for international customers' purchasing intentions and decisions, when a foreign digital product is immediately available through the Internet. Therefore, the role played by DEIs in economic distance should particularly be examined. Future research could look into the possibilities or threats to equality brought by the commercialization of digital products in international endeavors. Would digital products be available to international consumers presenting different incomes? What would be the pricing strategies of international firms when commercializing the same digital product in high- or low-income countries? Also, would the immediate knowledge availability facilitated by digital products lessen economic distance and thus enable more equal opportunities for consumers and firms from developing economies? We believe the research avenues looking into the effects of DEIs (and particularly with Born Global \& Digital firms) on the 
validity and relevance of the CAGE model of distance $[21 ; 48]$ present particularly significant avenues for future research that could see the crosspollination of various research areas.

Finally, another central tenet in international business research is internalization theory [10] that explains the governance mechanisms that firms use when internationalizing [13] to overcome threats of opportunism [58], and bounded rationality [52]. We believe the theory's basic assumptions of firms' reliance on firm-specific advantages (FSAs), and their combination with foreign partners' locationbound FSAs to compensate for their lack of knowledge of foreign markets [24] could lose explanatory power in digital-based business activities. In the context of digital firms, the role of foreign partners' resources and knowledge could become less important. In fact, the production and commercialization of value offerings rely entirely on digital infrastructure [39], which makes them immediately available to global marketplaces, and thus limits the need for foreign distribution partners. The entire value chain of Born Global \& Digital firms has the potential to be expressed in digital endeavors, and this might push them to rely on big players such as platforms and digital service providers such as Google (Android), Apple (iOS), Microsoft (Windows), rather than partnering with smaller players. Then, the liabilities typical of internationalizing ventures discussed earlier, such as newness, smallness, and foreignness, would turn into a liability of dependence. Consequently, there are implications for international strategy research, looking at a firm's competitive moves when dealing with mergers and acquisitions, or with resource control and deployment.

\section{Conclusions}

The aim of this paper was to bring new and clearer understanding of what constitutes a digital entrepreneurial internationalizer. We reviewed previous literature dealing with digitalization and clarified what constitutes a digital firm. We further reviewed previous studies dealing with digital entrepreneurship [39], international entrepreneurship [37], and discussed issues related to the time of internationalization [28]. Scrutinizing these streams of research and bundling the theoretical knowledge originating from them, enabled us to establish the theoretical basis to define and conceptualize the DEI. Based on criteria of digital and internationalization earliness and looking at examples from business practice, we outline four typologies of DEIs. By looking at their digital and international behavior, and their managerial relevance in today's business endeavor (with particular regard to the Born Global $\&$ Digital) we then discuss how they differ from traditional internationalizers and how this may impact some tenets of international business research.

In this paper, we discuss just some of the many theoretical aspects that might be affected by the inclusion of characteristics of digitalization in international entrepreneurship and business research. We suggest these, among others, should be considered when conducting research on international entrepreneurship, business, and systems sciences. In addition, we argue that the validity of the existing theoretical framework will be very much dependent on the type of firm investigated.

Therefore, it is necessary to pinpoint and clearly define different typologies of firms approaching international markets and deploying digitalization in some or many of their business functions. Accordingly, conceptualizing DEIs and defining the typologies under which the phenomenon appears helps us understand an increasingly relevant phenomenon in international business and digital entrepreneurial research streams. We would encourage future studies at the intersection of entrepreneurship, internationalization, and digitalization, as they could be particularly apt for generating new theoretical insights. Such studies could explicate the changes that digitalization has brought to international entrepreneurship and business.

\section{References}

[1] Afuah, A. (2013). Are network effects really all about size? The role of structure and conduct. Strategic Management Journal, 34(3), 257-273.

[2] Alvarez, S. A., \& Barney, J. B. (2007). Discovery and creation: Alternative theories of entrepreneurial action. Strategic entrepreneurship journal, 1(1-2), 11-26.

[3] Arenius, P., Sasi, V., \& Gabrielsson, M. (2005). Rapid internationalisation enabled by the Internet: The case of a knowledge intensive company. Journal of International Entrepreneurship, 3(4), 279-290.

[4] Autio, E. (2017). Strategic entrepreneurial internationalization: A normative framework. Strategic Entrepreneurship Journal, 11(3), 211-227.

[5] Autio, E., Nambisan, S., Thomas, L. D., \& Wright, M. (2018). Digital affordances, spatial affordances, and the genesis of entrepreneurial ecosystems. Strategic Entrepreneurship Journal, 12(1), 72-95.

[6] Autio, E., Sapienza, H. J., \& Almeida, J. G. (2000). Effects of age at entry, knowledge intensity, and imitability on international growth. Academy of Management Journal, 43(5): 909-924.

[7] Baber, W.W., Ojala, A., \& Martinez, R. (2019) Effectuation logic in digital business model transformation: 
Insights from Japanese high-tech innovators. Journal of Small Business and Enterprise Development 26(6/7), 811830.

[8] Berry, H., Guillén, M.F. \& Zhou, N. (2010). An institutional approach to cross-national distance. Journal of International Business Studies 41(9), 1460-1480.

[9] Brouthers, K. D., Geisser, K. D., \& Rothlauf, F. (2016). Explaining the internationalization of ibusiness firms. Journal of International Business Studies, 47(5), 513-534.

[10] Buckley, P. J., \& Casson, M. (1976). The future of the multinational enterprise. New York: The McMillan Company.

[11] Catalini C, Gans JS. 2016. Some simple economics of the Blockchain. In MIT (Ed.), Social Science Research Network. SSRN.

[12] Chandra, Y., \& Coviello, N. 2010. Broadening the concept of international entrepreneurship: Consumers as international entrepreneurs. Journal of World Business, 45(3): 228-236.

[13] Chi, T. (2015). Commentary: Internalization theory and its relation to RBV and TCE. Journal of World Business, 50(4), 634-636.

[14] Constantinides, P., Henfridsson, O., \& Parker, G. G. (2018). Introduction - platforms and infrastructures in the digital age.

[15] de Reuver, M., Sørensen, C., \& Basole, R.C. 2017. The digital platform: a research agenda. Journal of Information Technology, 33(2): 124-145.

[16] Eisenmann, T., Parker, G., \& Van Alstyne, M. (2011). Platform envelopment. Strategic Management Journal, 32(12), 1270-1285.

[17] Eisenhardt, K. M., \& Martin, J. A. (2000). Dynamic capabilities: what are they? Strategic management journal, 21(10-11), 1105-1121.

[18] Evans, D.S., Schmalensee, R. 2010. Failure to launch: Critical mass in platform businesses. Review of Network Economics, 9(4).

[19] Fraccastoro, S., \& Gabrielsson, M. (2018). Effects of Social Media Usage on the Speed of International Growth of an International New Venture. In Proceedings of the 51st Hawaii International Conference on System Sciences. Hawaii International Conference on System Sciences.

[20] Gabrielsson, M., Kirpalani, V. M., Dimitratos, P., Solberg, C. A., \& Zucchella, A. (2008). Born globals: Propositions to help advance the theory. International business review, 17(4), 385-401.

[21] Ghemawat, P. (2001). Distance still matters. Harvard business review, 79(8), 137-147.

[22] Hannan, M.T. \& Freeman, J. (1984). Structural inertia and organizational change. American Sociological Review, 49, $149-164$.

[23] Henfridsson, O., Nandhakumar, J., Scarbrough, H., \& Panourgias, N. 2018. Recombination in the open-ended value landscape of digital innovation. Information and Organization, 28(2): 89-100.

[24] Hennart, J. F. (2009). Down with MNE-centric theories! Market entry and expansion as the bundling of MNE and local assets. Journal of International Business Studies, 40(9), 1432-1454.
[25] Hylving, L. (2015, January). Competing values in the era of digitalization. In 2015 48th Hawaii International Conference on System Sciences (pp. 4161-4170). IEEE.

[26] Johanson, J., \& Vahlne, J. E. (1977). The internationalization process of the firm - a model of knowledge development and increasing foreign market commitments. Journal of international business studies, 8(1), 23-32.

[27] Johanson, J., \& Vahlne, J. E. (2009). The Uppsala internationalization process model revisited: From liability of foreignness to liability of outsidership. Journal of international business studies, 40(9), 1411-1431.

[28] Jones, M. V., \& Coviello, N. E. (2005). Internationalisation: conceptualising an entrepreneurial process of behaviour in time. Journal of International Business Studies, 36(3), 284-303.

[29] Kallinikos, J., Aaltonen, A., \& Marton, A. 2010. A theory of digital objects. First Monday, 16(6).

[30] Kallinikos, J., Aaltonen, A., \& Marton, A. 2013. The Ambivalent Ontology of Digital Artifacts. MIS Quarterly, 37(2): 357-370.

[31] Karhu K, Gustafsson R, Lyytinen K (2018) Exploiting and defending open digital platforms with boundary resources: Android's five platform forks. Information Systems Research. 29(2): 479-497.

[32] Kelestyn, B. \& Henfridsson, O. (2014). Everyday digital entrepreneurship: The inception, shifts, and scaling of future shaping practices. Proceedings of the International Conference on Information Systems, Auckland, NZ.

[33] Knight, G. A., \& Cavusgil, S. T. (1996). The born global firm: A challenge to traditional internationalization theory. In Cavusgil, S., \& Madsen, T. Eds. Advances in international marketing (Vol. 8). Greenwich, CT: JAI Press.

[34] Knight, G. A., \& Cavusgil, S. T. (2004). Innovation, organizational capabilities, and the born-global firm. Journal of International Business Studies, 35, 124-141.

[35] Knight, G. A., \& Liesch, P. W. (2016). Internationalization: From incremental to born global. Journal of World Business, 51(1), 93-102.

[36] Kumar, V., Choi, J. B., \& Greene, M. (2017). Synergistic effects of social media and traditional marketing on brand sales: capturing the time-varying effects. Journal of the Academy of Marketing Science, 45(2), 268-288.

[37] McDougall, P. P., \& Oviatt, B. M. (2000). International entrepreneurship: the intersection of two research paths. Academy of management Journal, 43(5), 902-906.

[38] Monaghan, S., Tippmann, E., \& Coviello, N. (2019). Born digitals: Thoughts on their internationalization and a research agenda. Journal of International Business Studies, $1-12$.

[39] Nambisan, S. (2017). Digital entrepreneurship: Toward a digital technology perspective of entrepreneurship. Entrepreneurship Theory and Practice, 41(6), 1029-1055.

[40] Ojala, A., Evers, N., \& Rialp, A. (2018). Extending the international new venture phenomenon to digital platform providers: A longitudinal case study. Journal of World Business, 53(5), 725-739. 
[41] Ojala, A., Rollins, M., Fraccastoro, S., \& Gabrielsson, M. (2020). The Internationalization of B2B Digital Platform Providers: The Role of Cross-National Distance and Digital Characteristics. In Proceedings of the Annual Hawaii International Conference on System Sciences. University of Hawai'i at Manoa.

[42] Oliver P, Marwell G, Teixeira R (1985) A Theory of the Critical Mass. I. Interdependence, Group Heterogeneity, and the Production of Collective Action. American Journal of Sociology. 91(3): 522-556.

[43] Oviatt, B. M., \& McDougall, P. P. (1994). Toward a theory of international new ventures. Journal of international business studies, 25(1), 45-64.

[44] Oviatt, B. M., \& McDougall, P. P. (2005). Defining international entrepreneurship and modeling the speed of internationalization. Entrepreneurship theory and practice, 29(5), 537-553.

[45] Parker, G. G., Van Alstyne, M. W., \& Choudary, S. P. (2016). Platform Revolution: How Networked Markets Are Transforming the Economy? and How to Make Them Work for You. WW Norton \& Company.

[46] Rennie, M. W. (1993). Born global. McKinsey Quarterly, 4: 45-52.

[47] Servais, P., Madsen, T. K., \& Rasmussen, E. S. (2006). Small manufacturing firms' involvement in international e-business activities. Advances in international marketing, 17, 297-318.

[48] Shaheer, N. A., \& Li, S. (2018). The CAGE around cyberspace? How digital innovations internationalize in a virtual world. Journal of Business Venturing.

[49] Shane, S. (2012). Reflections on the 2010 AMR decade award: Delivering on the promise of entrepreneurship as a field of research. Academy of Management Review, 37(1), 10-20.

[50] Shane, S., \& Venkataraman, S. (2000). The promise of entrepreneurship as a field of research. Academy of management review, 25(1), 217-226.

[51] Sigfusson, T., \& Chetty, S. (2013). Building international entrepreneurial virtual networks in cyberspace. Journal of World Business, 48(2), 260-270.

[52] Simon, H. A. (1955). A behavioral model of rational choice. The quarterly journal of economics, 69(1), 99-118.

[53] Stinchcombe, A.L. (1965). Social structure and organizations. In J.G. March (Ed.), Handbook of organizations (pp. 142 - 193).Chicago: Rand McNally \& Firm.

[54] Srinivasan, A. \& Venkatraman, N. (2017). Entrepreneurship in digital platforms: A network-centric view. Strategic Entrepreneurship Journal, 12(1), 54-71.

[55] Tiwana, A. 2013. Platform Ecosystems: Aligning Architecture, Governance, and Strategy. Amsterdam: Morgan Kaufmann.

[56] UNCTAD. 2017. Investment and the digital economy. Geneva: World Investment Report.

[57] Vadana, I. I., Torkkeli, L., Kuivalainen, O., \& Saarenketo, S. (2019). Digitalization of companies in international entrepreneurship and marketing. International Marketing Review.

[58] Williamson, O. E. (1985). The Economic Institutions of Capitalism. New York: The Free Press.
[59] Yoo, Y. 2012. Digital Materiality and the Emergence of an Evolutionary Science of the Artificial. In P.M Leonard, B.A. Nardi, and J. Kallinikos (Eds.), 134-154. Materiality and organizing: Social interaction in a technological world. UK: Oxford Press.

[60] Yoo, Y., Henfridsson, O., \& Lyytinen, K. 2010. The New Organizing Logic of Digital Innovation: An Agenda for Information Systems Research. Information Systems Research, 21(4): 724-735.

[61] Zaheer, S. (1995). Overcoming the liability of foreignness. Academy of Management Journal, 38(2), 341363.

[62] Zaheer, S. (2002). The liability of foreignness, redux: A commentary. Journal of International Management, 8(3), 351- 358. 